\title{
Analyzing Mythologia in Simin Daneshvar's Works
}

\author{
Farzaneh Moonesan ${ }^{1}$ \\ ${ }^{1}$ School of Literature, Guilan University, Rasht, Iran \\ Correspondence: Farzaneh Moonesan, School of Literature, Guilan University, Rasht, Iran. E-mail: \\ sahar51960@yahoo.com
}

Received: January 12, 2014 Accepted: March 6, 2014 Online Published: April 14, 2014

doi:10.5539/ach.v6n2p21

URL: http://dx.doi.org/10.5539/ach.v6n2p21

\begin{abstract}
Literary works have a direct interaction with the socio-political and historic evolutions which affect the literature of their period; therefore, the literary works are the looking glass through which the contexts of socio-political and historic aspects are reflected. The myths and archetypes are social elements always been the devices used in literature to express thoughts and ideas through epical genres and in more restricted sense contributing to the non-epical genres revealing the facts and semi-facts from ancient times. The human of the knowledge era in his/her contemporary achievements in the field of literature cannot ignore mythologia and has applied it in his/her works in a variety of manners. Daneshvar is one of such literary figures, who faced socio-political problems and applied the mythologia as a device to express her thoughts and demands on the issue of struggle against colonialism and protection of the national dignity as well as the women's right, the oppressed stratum of her society at that period.
\end{abstract}

Keywords: archetype, epical genres, Goddess, historic evolution, myth, national dignity, oppressed stratum, socio-political, Suvashun

\section{Introduction}

Ostooreh, the (Arabic) form of Historia (Greek) form, represent the myth in English. Myth consists of traditional tales and narrations which explain and describe the origin of life principles, the natural forces and the religious or other kinds of beliefs in the format of Gods and Goddesses in every tribe and nation. By reviewing the myths the reflection of the truth about social fiber, civilization and other elements that constitute a nation's identity are revealed.

Myths are unique to the ancient world, while they still have their influence on contemporary human thought. One pattern that is being followed in today's story writing is involved in themes that reflect myth. Simin Daneshvar is influenced by this pattern. Mythology in her works is the most applicable instrument selected to express her views through writing. The above mentioned notion and her specific stance in narrative literature with respect to the share of women writers in Iran and her efforts in promoting this sector call for a multi dimensional study on her works inevitable.

Regarding her viewpoints and tongue in literature many works are presented, while no analysis is made in a comprehensive and coherent manner on her mythologic writings. This article seeks to review and reveal her narrations with a descriptive-analytic approach while analyzing causation of recreating the mythical themes.

\section{Introducing Simin Daneshvar's works}

She gained fame by her "Suvashun" romance. The "The extinguished fire" (1948) containing 16 short stories (in a very sensitive feminine tongue with an emphasis on feminine affections), "A city like paradise" (1961) containing 10 short stories with an (exposition of the dispersed faces of Iranian women and other suppressed stratum of the society) and "Ask the migrating birds" (1997) 11 of different issues are the rest of her outstanding works.

Her attending the story writing classes in Stanford University changed her style, especially her story fabrication method. After her return, here outstanding works include: "Suvashun" (1969), "The island of confusion" (1991) and the "The confused cameleer" (2001). Her last work is the "Selection" (2007) which includes the collection of "Ask the migrating birds" and a few more short stories. 


\section{Daneshvar and Mythicization}

In most of her works signs and symbols that bond the character to the mythic characters and issues are evident. With no doubt her education in Art and Literature has contributed to her notion in mysticism. She was born and grown in birth place of Hafez, one of the greatest mythic poets, in the vicinity of Achemanians where the historic and national elements promoted her interest in mythology. Her love of Shiraz is reflected in her "Suvashun" romance: no Shiraz no national identity. Her faith in birthplace as a major identity factor for one self was nurtured by her forefathers' sense of socio-cultural values' protection. In her days the struggle against colonialism and oppression became evident through her challenges in supporting her husband, the famous modern Persian Poetry poet Jalal Al Ahmad. In the beginning years of 1950s the nation was going through a period of yearning, silence and seclusion in its cultural sense. The circumstances provided the opportunities for the writers to pursue nationalism. The writers in romance genre, not accepting the turmoil in their great nation tried to create works by introducing the historic and mythic heroes in order to push aside the bitter and harsh realities of the period and were trying to fly to their idealized utopia in the far past and find happiness in the ancient mythic sense.

Daneshvar was one of the devotees to the fact mentioned above. Her main motive in such writings is based on the socio-political background of that period. For instance resistance against colonialism in her mind-frame is reflected in "Suvashun" where "heroism" and "utopianism" are the causation of the events in the story. Her other major concern as a brain-child is the unpleasant socio-economic condition of women in the society of that period. Consequently she chose mythic heroism in her stories to deal with this bitter fact.

A) Heroism as an objective for standing against colonialism

In "Suvashun" she created a mythic-epic story with a tragic texture where women stood up against social issues, a reflection of the regrettable conditions in the contemporary history of Iran. This romance points to the picture of a myth through a modern narration the themes of which are the epical heroes, archetypes and specific mythic symbols.

The main notion of the romance is to discuss the challenging human nature. In the course of the romance we see the conflict between Yousof, the hero of the romance and the people who have sold their soul to the evil. Yousof is martyred during the conflicts between what is the existing bitter reality and what is the ideal and this makes Zari his wife and others to become aware. As we all know the common features in all myths are the conflict between good and evil and of course a hero, the symbol of goodness who seeks to martyrdom for his kinds. In "Suvashun" Yousof gives his life on his ideas in order to represent the real life to his society and the generations to come.

Yousof, in this romance is inspired by Yousof the prophet, Imam Hussein and Siyavash, all renowned symbolic personalities.

Yousof, the prophet goes to help people during a draught and tries to be just and fair when distributing flour among people. A similar behavior is seen on the part of Yousof, the hero of this romance; our Yousof symbolizes Imam Hussein who struggled against cruelty and became martyred in a foreign land away from home. And both were aware of their fate in different time zones.

Our Yousof symbolizes Syavash, the Iranian mythic hero of Shahname, a virtuous man who conquered the sensual passion and did not betray Soudabe, his foster-mother and is forced to leave home due to the sabotage planned by the same woman and go to Touran's land and become de-headed in an unjust battle and be left under open sky where no one mourned for him. Our Yousof was left alone among the army of enemies. His funeral service was disturbed and he was buried at night in presence of his family.

The title of the story "Suvashun" is a reminder of the traditional mourning ceremonies of Siyavash. Here, Daneshvar bounds the oppressed Siyavash to innocence of Yousof and tries to address the issue of victimization of the oppressed through colonialism of her days to the contemporary audience.

Siyavash is the symbol of Life and Death, an archetype. In Iranian mythology the growth of a plant from where Siyavash's blood was shed symbolizes his re-birth. In "Suvashun" the interpretation of the tree grown in Yousof's home makes him an archetype. Mak-Mahoon another character of this romance, during consolation, tells Zari "Do not cry my sister; a tree will be sprout in your home" (Suvashun, p. 303).

There exists a similarity between Siyavash and Yousof's death. In the mourning ceremonies of both the "Suvashun" (the special passion theater for Siyavash) took place. In the descriptions of this special ceremony one outstanding point is: Siyavash's horse is decorated with a black shawl tied around its neck in addition to the helmet, belt and the boots tied together hung on the horses' neck (Ibid, p. 210). 
The same scenario was repeated during Yousof's mourning ceremony. Daneshvar writes "The writes "The horse was decorated, the back of the horse was covered with black cloth; Yousof's hat was hung on mourning ceremony banner and his sward was hung on the horse's neck. Another simile is in their Totemisim towards their horses. Siyavash passed the fire test with the assistance of his horse "Shabrang". In "Suvashun" the presence of horse that belongs to Khosrow- not an ordinary horse- is outstanding. In "Suvashun" we face a new ideology. Here the character of Zari is the ideal woman. If Hasty, the woman character of the "Confused Island" represents the confusion of her days, no such element is observed in Zari after her husband, Yousof"s death.

At this time the "Siyavoshoon" a mythic plant begins to grow in the heart of a woman named Zari, a symbol of revenge against illiteracy, she is the one who after Yousof's death, once more, seeks to save Hasty. Before Zari's husband's martyrdom she used to calm him down but after his martyrdom the conditions changed drastically; she woke up and arranged the "Suvashun" ceremony for Yousof. At the end of the romance, Yousof's death is viewed as an element in national identity concept, something that makes Zari and many others in the society aware of what is being lost.

Yousof is the symbol of Iranian intellect (just like Jalal Al Ahmad), who stands against colonialists and traitors and speaks loud in the contemporary history of Iran. Being the wife of such character, Daneshvar would have absorbed her husband's notions to a point that similarities are found in their life and thoughts. In "Suvashun" Yousof resembles Jalal as far as the harsh, direct, extremist, angry and adventurous features of a character of a man are concerned. Daneshvar claims that Jalal was never a conservative or prudent. He could not stand corruption and "dirty hands". They fought against colonialism very bravely. In this romance Yousof is Jalal (A review on "Island of confusion, p. 399). Daneshvar says "my intention is to write a philosophical romance through "Suvashun" and prove that history repeats itself. I wanted to say that the martyred Johanna and imam Hussein had a similar faith just like that of Siyavash and Yousof... (The conflict between the image and the painter in Daneshvar's works, p. 74).

Most of Daneshvar's stories have traditional, national and religious taste, color and essence, while reflecting the contemporary socio-historic elements. For instance, on one hand in "Suvashun" she reflects the socio-political and the economic conditions of the city of Shiraz during WWII: the affairs of natives with the foreigners, the influence of WWII on Iran, the diseases, religious conflicts, central government oppressions, ethnical and regional conflicts etc. ; while, on the other, she goes back for centuries to breathe life to Iranian mythic characters who have been through similar situations back then and created the epical-mythical national wealth.

Daneshvar's mission is to keep people aware and change the passive attitude in the society to an active one, a society that takes life as it comes. Her nostalgic conception of the issue has pushed her towards applying mythology in her works. In "Suvashun" she gives Yousef a semi-human character, a reminder of the ancient Iranian mythicism by emphasizing that the struggle against colonist and oppressors should be founded on Iranian national-cultural-religious teachings and doctrines.

The concept of a plant's growth where a hero's blood is shed is rooted in the mythology which is respected in Daneshvar's works. In her story "The borderline and the mask" she believes that "Flower bunches would grow wherever the young soldiers' blood was shed during the Revolution" (Suvashun, p. 9). In "Suvashun" she has it "Zari went to sleep", in her dream she saw a big tree is grown in their garden and the gardener is pouring blood at its foot" (Ibid p.215). This dream symbolizes the Tree of Freedom and Liberalism which needs the innocents' blood for its survival.

In "Suvashun" Mak-Mahoon recited a poem where the tree of independence nurtured by soil and blood has a gardener like the Prophet. When the gardener yells 'blood' the people gather around the tree, cut their wrist-vein, pour blood at the tree's root, dry their wrists, put the scar on their eyes while accepting this phenomenon by heart and soul, they are changed in a full man capable of becoming a hero... this tree needs blood for growth"( Ibid p.38)

In "Suvashun" Mrs. Fotoohi, in jail, says "All these narcissuses that you see replace the blood coughed through my parents' throat" (Ibid, p. 215).

B) The Utopia

To Daneshvar a utopian society is distanced from lies, poverty and disorder. In her "The Island of confusion" Hasty, addresses the formation of the Utopia "Hasty sought for calmness, vigor and frankness. Would 'lie' one day leave this planet after which all sayings, thoughts and actions would become pleasant (Island of Confusion, $p$. 295). 
One of the oldest wishes of human being has been the creation of Utopia. In Zoroastrian beliefs having a world without the challenges between good and evil, light and darkness established the essential bases in human faith for eras to come. They formed a myth where the messenger of peace would end this situation and the world will be led by nothing but kindness. In "The confused cameleer", Tootia (the parrot chick) Daneshvar's soul's symbol says the following to calm her soul, "oppression and disorder prevails the world and the smoke of sadness has made the world smoggy. It would take time for the sapling of love to grow in peace and destroy wickedness ... many generations after you and all nations would enter a peace act. The God inside human would motivate people in a manner where the whole land on earth would be of a nation and all worldly needs would be fulfilled. The common Devine heritage is to bound human with human and human to God and love in the texture of the terrestrial guiding light be the victorious" (Confused Cameleer, p. 203).

The themes of Daneshvar's romances are full of comments and objections. In a way she seeks to present a picture of the retarded nature of the oppressive rulers and in other she nourishes the wish of Utopia in her mind. This is evident in her "The Island of Confusion", symbolizing Iran where the emotional complexities of the society are exposed.

\section{C) Benefiting from national-religious myths}

Daneshavr has applied many national-religious domestic myths' conceptions and beliefs in her works.

The creation of human: the essence of the "Elementum" story from the "Selection" is based on the Iranian ancient mythology. The main characters here are two lovers who have to pick two branches of rhubarb and pick two white flowers by the order of the sage. To the sage this collection is the foundation of the lover's creation, "The stone would say 'The national-religious myths of your creation consist of these two branches of rhubarb and these two flowers', be proud and praise the God" (Selection, p. 14). In Iranian mythology that the rhubarb is generated from Kiumars' back and the first couple is created by this plant is evident. This issue is related to totemism resource. To make it simple: in the course of human thought there has been a period where human thought of himself as he was directly born from a holly object or animal.

The white flower's presence signifies the plant phase of life next to the rhubarb branch, a mythic perception emphasized in "Elementum" story.

Daneshvar in "Suvashun" deals with the Iranian mythic expressions and rituals on the New Year ceremony, of course on behalf of Ganjour, Hasty's foster father. For instance, regarding the Nowrooz and the special house-cleaning before the New Year she says "In Nowrooz the world begins anew, the Nowrooz celebration is the celebration of the Earth and Sky's re-birth. The Godly spirits, from the name of which the first month of Iranian calendar "Farwardin" is depicted from come to Erath and are hosted by the descendants. Mr. Crisly said "just like a Platonian facsimile". Ahmad said "Plato has copied us ... at the beginning hours of the new year the deceased are guests of the descendants and participate in the family's celebration; therefore the house should be clean and tidy, the clothes must be new and clean and the food must be plenty and the stove should be lit. If the deceased see their descendants' mood wretched, and notice that they are not in peace with one another, they get offended from the situation and leave (Confused Cameleer, p. 128).

A symbolic story in a completely mythic atmosphere which has engulfed a complete chapter of "Suvashun" is about when Mak-Mahoon talks in behalf of the ultra human who seeks to develop an ultra-national narration by putting the myths of specific deities and the prophets of different religions and nations next to one another. In one sense he talks about Buddha and in the other about St. Mary's Godly table with plenty of food, Noah's pigeon and St. Gabriel wings ... in this story the old ultra human breaks the fate plaques and the wings of the Archangels and burns all the records and files of the ancient Gods. The child-angels give to human the stars, the symbol of their fate and say "take your star so you would know that you begin anew and are free and have to support yourself".

This issue is a broadening factor in the contemporary human's freedom as far as the national, tribal, religious aspects are concerned, a type of freedom created through negation of faith in God.

D) Mythicism with respect to protecting women's identity

Daneshvar's approach in selecting women character from different social stratum is a predetermined step. Exposing the problems and the difficulties of Iranian woman is a mission for her. In an interview she says "My duty is to show the Iranian women's subjectivity, not limited to the elite and the cultured. I have been in close contact with all at different social stratum and have noticed the following problems in the Iranian women's status: lack of financial independence, which make her a subject of the man; illiteracy which leads to her not having her own socio-political sense and the prevailing male dominancy in the society ... in general the image of Iranian 
women is covered with destitution, poverty and the ignorant of the concept of "right" (A review on "Island of confusion, p. 1009).

Daneshvar's stories are almost unique in addressing the women's issue in Iran. In most stories, in this regards, machismo prevails and feminism is almost overlooked. In "Suvashun" the woman identity is addressed through which the perception regarding character of woman is changed in a male dominant society. The women characters in Daneshvar's stories have a doubtful view to the men's world and values. One of the instruments that she uses in protecting the woman's identity is choosing the archetypes and myths where woman are respected and valued.

In her works the earth, deserts and seas even God are of feminine gender. For instance in "Confused cameleer" the cameleer said "the desert is like woman who makes man to fall in love" (Confused Cameleer, p. 194); or "the earth is like a mother who takes care of all her children, flowers and fruits etc". She emphasizes on the woman archetype, Anima and Animus

\section{The Archetype of Woman}

Myths are one of the cultural indices of a nation. When we refer to Iranian mythology the number of Goddesses reveals the women's value. They were considered as saints, since they were able to give birth and even were worshiped as Goddesses. All this changed when the feminine dominance era ended and the mythic narrations considered man as the main characters.

The main feature in Daneshvar's works is revealed when the society, women and myth are bound together. Zari as a wife and mother personifies the Iranian woman. The essence of "Suvashun" lies in the fact that during occupation of Fars province in the south by the British, a woman's struggle in spreading awareness becomes outstanding. Daneshvar ranks the soil of Shiraz as the Mother Earth, being overtaken by the British, and Yousof the child of this Land who seeks to save his mother. According to era of Goddesses the hero must be sacrificed in order for the Mother Earth to become fertile; so, Yousof's death rather than Zari's is necessary. Here Zari must stay alive as the Goddess, symbolizing Shiraz, fertilized with awareness. In "Island of Confusion", Hasty resembles Eve lost in the confused Island, as if this island is the Serendip (Note 1) Island and this initial woman is thrown, from the heavens of myths, on the contemporary confused world who becomes deeply confused in everything, be it love, youth or politics. But eventually through a secret conversation with her inner parrot-chick -the symbol of the intellective soul- she reaches a proportional calm which highly influences people around, as if all find their real stance next to her.

Another aspect of that contributes to crystallization of woman archetype in Daneshvar's works which could be the eternal woman in the "Elementum" story from "Selection" collection where you read "on the castle a woman is perched covered with wavy silky fabric". She resembled the woman who walks gracefully in the air; like the ones in miniature paintings, all abstracts and this eternal woman said "the greatest name is love; woman and man asked whether love is created by the woman? The eternal woman answered that love is bilateral, but if unilateral then is nothing than trouble (Selection, p. 20). In this story all the Goddess, the ideal woman and the eternal woman are illustrated.

In the ancient cultures, the woman, earth, moon, snake and cow symbolize fertility. The woman and Mother Earth were considered the closest, since mothers are the first creatures whom the new born encounters with and the earth is the first phenomenon around that mankind recognizes after realizing itself. This belief is reflected in Daneshvar's works; for example in the "Snake and the man: we read "the earth curses the single person and a person with no child" (Ibid, p. 109), "in the spring the earth, just like the mother takes care of all fruits and blossoms" (Ibid, p. 143). Nasrin knew that the crescent tiptoed at sunset to check the earth's fertility, paused a short while and left (Ibid, p. 116). In the myths the snake is connected to woman and feminism; "the snake accompanies the Goddesses and is the great mother. Snake is responsible for the descent of Adam from the heavens. All over the world snake is associated with fertility. This mythic creature symbolizes a dual-conception: life and death, good and evil, gain and loss; since it sheds skin, it symbolizes resurrection and since it kills, hence the locus of destruction and death (Women and myth, p. 64).

In the same story, one of the characters claims "I read in an Indian mythic book that the snake is a sign for earth, fertility, grace, the mediator between the earth and the skies..." (Greeting whom, p. 138). Dr. Bidkhaty said "the snake is the king of the earth, manifesting the water of life" (Ibid, p. 146). In one sense, according to such writers snake is the symbol of life and fertility and in another the manifestation of destruction and death. In this story Nasrin becomes pregnant and after nine months gives birth to a snake. By her husband's order she keeps the creature. The snake causes the destruction of Nasrin's Paradise-like garden and breathes discomfort to the people 
surrounding her. Nasrin said "the trees are withered; the fruits have dried on the trees, the greenery is trampled and the lotus ... (Confused Cameleer, p. 153).

In objection to the ancient belief that the woman was influenced by the snake in the causation of Adam's ejection from the heavens, Daneshvar applies the dual nature of the snake's myth and creates a story where man is one who convinced the snake to destroy the garden of paradise.

\section{The Anima and Animus Archetype}

Plato in his thesis "The feast" refers to a Greek myth in order to show that every human being needs its opposite gender. Apolune, by the order of Zeus, divided the initial humans into two halves. To gain the original status each half sought to join the other by wrapping their arms around the other's neck, but no success. Then all halves rebelled and decided not to perform anything without the other half; therefore, all got weak and died and the remaining alive halves had their arms around the other's neck. Zeus became merciful and solved this problem. Since then a mutual love entered human heart ... and as I said each one of us contains a half of the other, hence everyone looks for its other half" (The feas,p.33). This concept is valid even today. In this respect Carl C. Jung believes that this half is within one's self and says Anima is the manifestation of feminine nature in man' subconscious and Animus is that of the woman's. To Jung, Anima and Animus are the most important archetypes in personality evaluation (Man and His Symbols, p. 275). In "Suvashun", Soodabe, the Indian maid-dancer who had fallen in love with Yousof's Father refers to this archetype where equality of man and woman is based on each other's existence.

That night Zari asked Soodabe "you that have thousands of devotees, what have you found in my father due to which my mother has become a homeless? And she said "it is not of my will, I know I have defamed a Shia Molah and have made an innocent woman homeless, but it's beyond my control. One had a connection with someone in the previous life and then separated from but he/she keeps coming to this world in order to find that someone; that one suffers and waits and when finds the lost someone there is no way of releasing him/her. The myths have "At the beginning there were two plants joint together, one died. In the next life two birds lost each other on migrating rout. Two antelopes were in love, the hunter hit one, and other mourned. A lost son is found and brought to his father. Now, how can all these let go of the other". (Suvashon, p. 78)

In her writings Daneshvar suffices to the mythical symbols and characters in specific sense. Applying mythicism in her works has not served the story writing pattern but is presented in a perfunctory manner like pointing to evil creatures and the Phoenix... It seems that in a sense she refers to the mythical characters' immortality or her own vast knowledge in this field and/or transmitting information to the audience. These conceptions and beliefs regarding mythicism sometimes push Daneshvar towards such orientation through her subconscious mind.

Likewise in "The confused cameleer" Morad calls Hasty as his Anima "Suddenly I felt like Hasty has infused inside me. I lost my manhood; the fear of being emasculated horrified me.

\section{Conclusion}

In most of Daneshvar's stories the signs which indicate the bound between her created characters and mythic issues are evident. The major motive in her mythicization is her nostalgic notion in dealing with the socio-political issues. In the midst of the threatening great harm to the society and the presence of colonialists in addition to the cultural aggression a regressive look at traditions through the mythic channel was deemed necessary by Daneshvar for revitalizing the national identity. In her stories her emphasis is on the whole process of the myth's development process. This fact is more vivid in her "Suvashun" mythic-epic presentation in a tragic texture. The presence of the archetypes and specific symbols accompanied with the themes and epical heroism convert this romance into a mythic narration which adds to domestic and foreign religious mythology with a higher influence on the audience.

Daneshvar is a successful writer in describing the psyche and thoughts of the oppressed women of the society. In this respect she has resorted to the archetypes and myths where woman has been honored; the archetype of woman in Anima and Animus. The last word is that Daneshvar can be considered as a socio-political mythological writer.

\section{Reference}

Daneshvar. S. (1980). Greeting whom? Tehran, Kharazami Publication.

Daneshvar. S. (1993). Island of Confusion.

Daneshvar. S. (2001). Confused Cameleer.

Daneshvar. S. (2007). Selection (1st ed.). Tehran, Ghatre Publication. 
Daneshvar. S. (2011). Suvashun.

Dehbashi. A. (2004). A review on "Island of confusion”" (1st ed.). Tehran Sokhan Publication

Golshiri, H. (2000). The conflict between the image and the painter in Daneshvar's works (1st ed.). Tehran Nilofar Publication.

Plato. (2006). The feast. A word regarding love. Tehran, Jami Publication

Tavasoly. N .(2002). Women and myth. Mah Honar (pp. 60-68).

Yoong, K. (2010). Man and His Symbols (7st ed.). Tehran Jami Publication.

\section{Copyrights}

Copyright for this article is retained by the author(s), with first publication rights granted to the journal.

This is an open-access article distributed under the terms and conditions of the Creative Commons Attribution license (http://creativecommons.org/licenses/by/3.0/). 